УДК 16:165.74

DOI https://doi.org/10.32837/apfs.v0i29.956

\author{
М.В. Сінельнікова \\ ORCID ID: https://orcid.org/0000-0001-6085-6087 \\ кандидат філософських наук, доцент, \\ доцент кафедри філософії \\ Національного університету «Львівська політехніка»
}

\title{
НІЦШЕАНСЬКЕ ВІЧНЕ ПОВЕРНЕННЯ ЯК ШІЛЯХ ДО САМОГО СЕБЕ
}

Постановка проблеми. Ідея вічного повернення - це наскрізний стрижень, навколо якого Ніцше вибудовує всю свою філософську систему. Але в мислителя вона постає недосказаною, та цю «недосказаність» Ніцше зберігає свідомо, залишаючи питання вічного повернення завжди відкритим. Тому багато дослідників і нині рідко звертаються до цієї «тривожної» та надто "важкої» думки, обходячи ії стороною, вважаючи незрозумілою, поверхневою, малопереконливою та «зайвою» для цілісного сприйняття філософської спадщини Ніцше. Однак є чимала когорта «сміливців», які наважилися потрактувати ніцшеанську ідею вічного повернення. До їх числа можна віднести доробок Дельоза, Льовіта, Батая, Гайдеггера, Данто, Жигалкіна, Лютого, Гаріна, Унамуно, Хатаба, Кауфмана й інших.

Така різноманітна кількість інтерпретацій засвідчує багатогранність цієї ідеї, яку повністю охопити чи продумати до кінця практично неможливо. Тому метою статті є дослідження ніцшеанської ідеї вічного повернення в ії антропологічному ракурсі, а саме як можливості сходження людини до самої себе, iї повернення до власної сутності, що здійснюється через самоподолання та самовдосконалення. Усе це втілюється в ніцшеанській ідеї «надлюдини», яка трактується філософом як «покращена» версія нас самих через подолання в собі слабкої «останньої» людини за допомогою волі до влади або неймовірного самовладання.

Виклад основного матеріалу. Як вже зазначалося вище, ніцшеанська ідея вічного повернення завжди була предметом численних дискусій і сперечань. У цих суперечках можна виділити три принципові позиції, які займають дослідники. Представники першої позиції вважають Ніцше психічно хворим, а його ідею - симптомом і проявом цієї хвороби. Представники другої позиції відзначають, що Ніцше, бувши блискучим філологом, просто наслідує ідеї давніх авторів. Представники третьої позиції наполягають на тому, що ідея вічного повернення $є$ найглибшою та найбільш оригінальною його концепцією, та тому вимагає особливого й грунтовного дослідження.

Натяки дослідників першого табору на психічну хворобу Ніцше не відкривають нам нічого нового в ідеї вічного повернення, скоріше навпаки, вони нагадують заклики до ї̈ цілковитого ігнорування. Але не брати до уваги або заперечувати філософське значення цієї ніцшеанської ідеї означає поверхнево й несерйозно ставитися до всієї системної побудови мислителя. Мало того, іманентне й адекватне сприйняття філософської системи Ніцше неможливе без розуміння та трактування ідеї вічного повернення, яка постає її центральною темою та внутрішньою сутністю.

Звинувачення Ніцше в «плагіаті» представниками другої групи дослідників також видаються безпідставними. Проте варто визнати, що ідея вічного повернення й справді не нова й існувала задовго до своєї появи у вченні Ніцше. Ї̈̈ підгрунтя ми знаходимо у філософії піфагорійців, ідеях Геракліта й Платона, пошуках атомістів і стоїків, традиціях неоплатонізму й східних практиках, думках Екклезіаста, теоріях Макіавеллі, Монтеск'є та Віко. Але цілковито нового звучання вона набуває саме у філософії Ніцше, стаючи «його особистим духовним надбанням, одкровенням, досягненням, яке володіє позачасовою та позаособистісною цінністю та змістом» [7, с. 6]. Це засвідчує, що Ніцше ніколи не був чиїмось послідовником чи коментатором і все, що він писав, за його власним висловом, було «написано кров'ю» та пережито ним особисто. Тому саме його можна вважати «провісником» і «першоджерелом» ідеї вічного повернення [5, с. 112].

Ніцше й справді вважав іï своїм власним прозрінням, яке виникає як велика й переможна думка, що викликає переворот у його світогляді й відкриває йому абсолютно нову реальність. Це озаріння сходить на Ніцше раптово, як удар блискавки, й сам він описує це таким чином: «Тепер розповім я історію Заратустри. Основна концепція цієї роботи, думка про вічне повернення, ця найвища формула утвердження (die Bejahung), яка взагалі може бути досягнута, - належить до серпня 1881 року: вона накидана на листку паперу 3 написом: «6 000 футів по той бік людини і часу» . Я йшов у той день лісами біля озера Сільваплана; біля могутнього пірамідального каменю поблизу від Сурлея зупинився. Там і прийшла до мене ця думка» $[17$, с. 126$]$.

Пояснити своє осяяння, й тим більше донести його до інших Ніцше вважав неможливим, 
оскільки його можна лише пережити всім своїм єством. Тому, незважаючи на те величезне значення, яке філософ надавав вченню про вічне повернення, написав про нього він дуже мало та якось уривчасто, повідомляючи про нього ніби «пошепки» чи «по секрету». Вперше до ідеї вічного повернення Ніцше звертається у «Веселій науці» (1882 р.), вона зароджується саме там, як і всі інші його «прозріння». Але найбільш вичерпне їі формулювання ми зустрічаємо в «Заратустрі», якому й випадає честь стати «учителем вічного повернення» .

Однак ця ідея у творі не така очевидна, вона прочитується ніби «між рядків» та як невидимий чи ледь вловимий контекст «стоїть за найважливішими образами, думками, настроями, висловлюваннями, афоризмами» філософа [5, с. 117]. Взагалі всі твори Ніцше важко назвати наративами чи якоюсь однією, завершеною та цілісною концепцією, що викладається послідовно й раціонально. Це, швидше, гімни й заклинання, які намагаються щось донести читачеві, а саме думку про вічне повернення. Оскільки всі його твори це, по суті, лише підготовка до цієї найважливішої частини його фiлософіï. I, як помітно з його щоденників, Ніцше дуже багато думав над нею, плануючи написати ще не одну книгу про вічне повернення.

На перший погляд, сутність ніцшеанської концепції дуже проста: все повертається, знову й знову, нескінченно. «Позаяк кількість атомів, або незмінних першоелементів, конечна, то у вічному всесвіті має час від часу повторюватися та сама, що й тепер, їх комбінація, та, отже, вічну кількість разів має повторюватися те, що відбувається тепер» [11, с. 110]. Іншими словами, Всесвіт нескінченний, тоді як світ складається з конечного числа атомів, тому рано чи пізно все в ньому повинне повторитися: буде такий самий світ, будуть такі ж самі люди, як і ми. Аргументи для підкріплення цієї теорії відшукуються в самого Ніцше, який порівнював вічне повернення 3 киданням гральних кісток: в якийсь момент число всіх можливих комбінацій буде вичерпана й тоді вони змушені будуть повторитися знову [18, с. 135-136].

Але сам Ніцше був противником будь-якого атомізму чи фізикалізму в трактуванні ідеї вічного повернення. Він розуміє світ не як поєднання атомів і порожнечі, а як колосальну, але обмежену силу, єдину, але водночас дану у вигляді безлічі осередків енергії, фізичних і духовних, мислимих і немислимих, які безперервно змінюються, перетікаючи одна в одну, заповнюючи собою весь простір, який не терпить порожнечі. Таке трактування стосується онтологічного аспекту ідеї вічного повернення, який руйнує антропоморфне сприйняття природи, залишаючи людину нао- динці з могутністю хаосу, стихією становлення та життя, які є неосяжними й незбагненними.

Це дає змогу зрозуміти ніцшеанську ідею вічного повернення як форму прагнення до буття та можливість його утвердження, які постають не в образі годинникової стрілки, що повторює свій рух циферблатом (рання форма уявлення про вічне повернення в самого Ніцше), а як конфігурацію становлення. У цьому, на думку Гайдеггера, й полягає парадокс Ніцше: саме думка про вічне повернення дозволяє вловити світ у цілісності його становлення. Цей горизонт світу як становлення або вічного повернення того ж самого з'являється, народжується в сущому як «стрибок» $\mathrm{i}$ «звершення». Ці перерви й стрибки утворюють такі проріхи в сущому, які представляють буття як подію, буття як час [12, с. 205].

Такий погляд ніби зсередини «думки думок» розкриває ï таємничий сенс, який полягає в осягненні причетності миті й усього сущого до вічності. «Ось у чому моя розрада: все, що було вічне: море знову винесе все назад» [15, с. 165]. Так Ніцше увіковічує всі події, які відбуваються, адже для нього «все має значення, саме тому, що воно швидкоплинне. Я прагну вічності для кожної події... Я вірю, що все, що відбувається, вічне» [див. 3, с. 254].

Таке трактування вічного повернення виступає у філософії Ніцше еквівалентом безсмертя, бо, якщо "Бог помер», тоді немає ніякого вічного життя після смерті, а те, що людина помирає, було для філософа найбільш аморальним фактом i найбільшою його екзистенціальною тривогою. Тому немає ніякого "до» чи «після», все відбувається одночасно, тут і зараз. Ціле й частини, будь-який епізод і все наше життя, минуле й теперішнє, травинка й увесь Всесвіт постають як одне. Мить застигає у вічності, й ми разом 3 нею, як «комашки в бурштині».

Подібна перспектива не може не лякати, особливо слабку «останню» людину, яка сприймає вічне повернення подібного як нудьгу й прокляття. «Повернення безпричинної миті позбавляє життя мети й тим самим руйнує його. Повернення - це драматичний образ і маска цілісної людини: це пустеля для людини, кожна мить життя якої віднині позбавлена підстав» [1, с. 28-29]. Тому найсуттєвішою ознакою людини «рабської маси» Ніцше якраз і називає відсутність прагнення до набуття сенсу, коли людина не загадується над питанням «навіщо», не здатна ставити перед собою цілі, її амбіції здрібніли, як і здатність до напруження сил. Така людина позбавлена самовладання та стає рабом власних пристрастей, втрачає себе в хіті, ліні, марнославстві [9, с. 161].

3 огляду на це цілком доречним видається заклик Ніцше до «подолання» такої слабкої «останньої» людини. Однак це «подолання» 
філософ розуміє не зовсім у звичному для нас сенсі, оскільки «слабка» людина знаходиться не десь ззовні, поза нами, а всередині кожного 3 нас. На думку Ніцше, людина постає дуальною істотою, в якій рівною мірою представлена як слабкість, так і сила. У ній тісно переплетені й борються між собою «остання» людина й надлюдина, й хто врешті-решт переможе - залежить тільки від неї. Для цього Ніцше й знадобилося вічне повернення, в ході якого людина повинна пересилити й перестворити саму себе, тим самим перестворити й увесь світ. Усе повертається, і це повернення абсолютне, у всіх деталях, повним, буквальним поверненням. I центром цього повернення виступає кожна окрема людина, яка й викликає його до життя своєю напругою та внутрішньою боротьбою. Своєю ідеєю вічного повернення Ніцше ніби висловлює захоплення могутністю людської суб’єктивності й потенціалом їі особистісного начала.

У нього саме суб'єктивність $€$ «ім' ям такого незнищенного руху колом, сили, котра бореться не 3 певною зовнішньою потугою, що чинить їй опір $<$...>, а 3 абсолютно внутрішньою за своєю природою перешкодою, яка врешті-решт і «є» самим суб'єктом» [6, с. 184]. Водночас момент подолання не має завершеного характеру, оскільки неможливість остаточного подолання «надто людського» приводить до вічного повернення необхідності виконувати своє призначення. «Остання» людина знову й знову повинна бути подолана й повинна стати перспективою нового подолання та нового оновлення. Тому, коли новонавернений каже, що він знайшов у собі себе, Ніцше йому відповідає: «Так витримай себе у Вічності, якщо ти це ти» $[9$, с. 201].

Таким чином, філософ намагається змусити людину обернутися на саму себе, вказавши їй шлях до самовдосконалення. Тут ми зіштовхуємося 3 найповнішим формулюванням ніцшеанської ідеї як вічного повернення до Самого себе (des Gleichen), що «визначає значення стійкості становлення; в якому, таким чином, виникає необхідність повторення для кожної події всередині цього становлення» [2, с. 115]. Бачити в собі становлення та заперечувати в собі індивіда, щоб побачити світ якомога більшою кількістю очей, - тільки так, на думку Ніцше, ми можемо стати тими, ким ми є насправді - сильними особистостями. Тому лише той, хто «повернувся до себе», хто став «самим собою», може вважатися, за Ніцше, надлюдиною, новою людиною, «покращеною» версією себе самого.

Так, заперечуючи метафізичну телеологію, Ніцше переносить цільовий початок в особистісний простір людини: цілком можливо, що світ безглуздий і постійно повертається до самого себе, але сильна особистість не може прийняти цю без- глуздість і повинна всупереч вічному поверненню ставити й домагатися власних цілей [2, с. 279]. Тому для Ніцше з пастки вічного повернення $є$ лише один вихід - це надлюдина, яку він трактує не як «природний продукт подій або наслідок причин та обставин, але як якусь людську здатність здійснити вчинок, безосновну дію актом власної свободи й волі» [10, с. 44].

Свобода й визначення себе через себе - доля небагатьох обраних, сильних, що володіють волею та владою, які Ніцше пов'язує між собою, бо «воля в собі самій є влада, а влада - в-собі-постійне-воління (in-sich ständige Wollen)» [12, с. 43]. Щоб прагнути вічного повернення до життя, де знаходиться ідеальна програма людської самореалізації, і справді необхідна неабияка сила волі або воля до влади, точніше влади над самим собою. Саме вона підштовхує нас відірватися від марної ностальгії та приєднатися до становлення, стати на шлях творчості, на шлях творення самого себе.

Для такої людини-творця звістка про загальне повернення речей звучить як велика втіха й радість, оскільки вона усвідомлює, що творить щось незнищенне й вічне. Таким чином, вона відчуває себе врятованою від закону загальної плинності й знищення. «Безсмертна та хвилина, - говорить Ніцше, - коли я створив вчення про загальне повернення: заради цієї хвилини я можу витримати загальне повернення» [9, с. 83]. Так ніцшеанське повернення наближає людину до вічного й нескінченного, яке, з одного боку, руйнує її повністю та абсолютно, а з іншого, - повертає її до власної сутності.

У зв'язку із цим Ніцше використовує відомий вислів: «Стань тим, ким ти є!», або інший його варіант: "Ми хочемо стати тим, ким ми є, $<$... $<$ тими, хто сам собі законодавець, сам собі творець!» [16, с. 243]. Наголос тут робиться саме на активному самостановленні людини, а вічне повернення стає тим пробним каменем, який повинен встановити відмінність між людьми й усунути тих, хто втомився від життя. Тому, як стверджує Дельоз, повертається тільки те, що утверджується та що веде до становлення, лише те, що активне. Нi реактивні сили, ні воля до заперечення не повторюються: вони усунуті завдяки трансмутації, завдяки вічному поверненню, яке здійснює вибір [4, с. 156].

Завдяки цьому людина підіймається до найвищого утвердження життя, яке виражається Ніцше ідеєю “amor fati” (любов до [своєї] долі лат.) і є проявом людської волі до вічного повернення. Так, Ніцше пов' язує своє вічне повернення з двома основними поняттями, які він стверджує та примиряє - становлення та цінність існування, - тим самим долаючи традиційну спробу їх розрізнення, а також намагаючись віднайти мету й сенс не лише в «бутті». Тому вічне повернення - 
це «дещо набагато більше, ніж просто психологічний чи особистий заклик життєствердження» $[13$, с. 57]. Оскільки питання про сенс лежить в основі всього культурного значення, потужний концентраційний ефект вічного повернення привертає увагу до довершеності, яка є неминучим випробуванням для будь-якого інтелектуального проєкту.

Також для кращого розуміння сутності ніцшеанського задуму варто відзначити, що вічне повернення подібного, про яке говорить філософ, потрібно відрізняти від повторення того ж самого, з яким його часто плутають і навіть ототожнюють. Оскільки «повторення саме цього життя - це не зовсім повторення, бо ми проживаємо його завжди ніби заново, ніби вперше, не знаючи про те, що воно повторюється" [5, с. 124]. Якщо ми знову повернулися, тоді ми маємо можливість знову дати цьому світу свою відповідь на виклик долі, який вона кидає нам тепер. I коли людина знову опиняється перед тим самим викликом, вона має можливість у цій точці-миті прийняти єдине, абсолютно правильне рішення.

Так у людини 3'являється шанс виправити «старі» помилки, до яких вона раніше була не готова чи не мала досить досвіду для їх розв'язання. Саме тому в «пульсі Всесвіту події не тільки повторюються, але й повертаються, щоб стати відправною точкою нових змін” [8, с. 857]. $\mathrm{y}$ цій точці ми можемо все розв'язати заново. Новий старт, нове рішення. Тому в людині, яка віками повертається до себе самої, все ж таки щось змінюється, з'являється якась нова особистість, яка в чомусь зовсім не подібна на себе попередню. Так в ніцшеанській ідеї вічного повернення проступає можливість змін, які, на перший погляд, неможливі за умови вічного повернення подібного.

Крім того, стає зрозумілим, чому вічне повернення перетворюється на необхідний елемент життя, магнетизм якого був таким привабливим для Ніцше. Мислитель понад усе прагнув вічності, нехай навіть у вигляді вічного повернення. Адже так людина не зникає в безодні небуття, а вічно відновлюється до життя. Усі минулі подібні ситуації, які зливаються в теперішньому в щось одне, насправді лише різні сторони й ракурси цієї реальності. Минуле повертається, з'єднується 3 теперішнім і постає як якась цілісна ситуація, до якої ми були причетні раніше й до якої ми будемо причетні завжди. У цьому весь Ніцше, який прагнув «пояснити все одним ударом, одним словом» і розгадати Всесвіт однією фразою" [14, с. 239], однією думкою та ідеєю - вічним поверненням того ж самого.

Висновки. Ніцшеанська ідея вічного повернення - це складний комплекс переживань, виключних станів і настроїв, думок і прозрінь. Тому вона така багатогранна й складна, це як

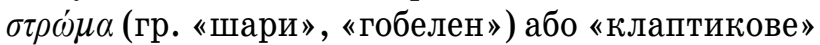
покривало, сплетене з тисячі різних ниточок, потягнувши за які, ми щоразу будемо отримувати абсолютно інше її розуміння та трактування. I немає сенсу збирати ці шматочки ніцшеанської «головоломки» докупи, оскільки вони набагато цікавіші саме своїм розрізненням. Перспективи подальших пошуків. Здійснене дослідження ніцшеанського вічного повернення допоможе надалі розширити межі традиційного розуміння ідеї, стимулюючи водночас грунтовні розвідки щодо можливостей людського самовдосконалення та самореалізації.

\section{Jimepamypa}

1. Батай Ж. О Ницше / Пер. с франц. А.Д. Бакулов. Москва : Культурная революция, 2010. 336 с.

2. Гарин И.И. Ницше. Харьков : Фолио, 2019. $508 \mathrm{c}$.

3. Данто А. Ницше как философ / пер. с англ. А.А. Лавровой. Москва : Идея-Пресс: Дом интеллектуальной книги, 2001. $258 \mathrm{c}$.

4. Делёз Ж. Различие и повторение. Санкт-Петербург : «Петрополис», 1998. 384 c.

5. Жигалкин С.А. Об иных горизонтах здешнего: Апология вечного возвращения. Москва: Издательский Дом ЯСК, 2019. 320 c.

6. Жижек С. Психоаналіз та постмарксизм. Випадок Алана Бадью. Етика. Нарис про розуміння зла / А. Бадью ; Пер. з фр. В.В. Артюха та А.А. Рєпи. Київ : Комубук, 2019. С. 149-190.

7. Лёвит К. Ницшевская философия вечного возвращения того же / пер. с нем. В.М. Бакусева. Москва : Культурная революция, 2016. $336 \mathrm{c}$.

8. Лютий Т.В. Ніцше. Самоперевершення. Київ : Темпора, 2017. $978 \mathrm{c}$.

9. Ніцше Ф. Так казав Заратустра. Жадання влади. Київ : Основи, 1993. 362 с.

10. Соловьева С.В. Власть и событие. Вестник Самарской гуманитарной академии. Серия «Философия». 2007. № 1. C. 42-53.

11. Унамуно М. де. О трагическом чувстве жизни. Киев : Символ, $1996.416 \mathrm{c}$.

12. Хайдеггер М. Ницше. В 2 т. Т. 1. Санкт-Петербург : Владимир Даль, 2006. 608 с.

13. Hatab L.J. Nietzsche's Life Sentence: Coming to Terms with Eternal Recurrence. New York: Routledge Taylor \& Francis Group, 2005. 218 p.

14. Kaufmann W. Nietzsche: Philosopher, Psychologist, Antichrist. Princeton, New Jersey : Princeton University Press, $2013.560 \mathrm{p}$.

15. Nietzsche F. Der Wille zur Macht. Frankfurt : Voltmedia, Paderborn, 2015.410 S.

16. Nietzsche F. Die Fr hliche Wissenschaft. Köln : Anaconda, 2012.320 S.

17. Nietzsche F. Ecce homo. Wie man wird, was man ist. Berlin : Holzinger, 2016. $163 \mathrm{~S}$.

18. Nietzsche F. Nachgelassene Fragmente 1882-1884. Berlin : de Gruyter. 1980. $336 \mathrm{~S}$. 


\section{Анотація}

Сінельнікова М. В. Ніцшеанське вічне повернення як шлях до самого себе. - Стаття.

Стаття присвячена дослідженню ніцшеанської ідеї вічного повернення та проблемі ऑï різностороннього трактування. Зауважено, що такий концепт є фундаментом всієї ніцшеанської філософії, який об'єднує в єдине ціле інші ключові ідеї мислителя, такі як надлюдина, «остання» людина, воля до влади, «смерть» Бога, amor fati. Наголошено, що людина зображується Ніцше як дуальна істота, оскільки в ній рівною мірою представлено два протилежних начала - людське й надлюдське. Підкреслено, що, на переконання Ніцше, кожен із нас потенційно вже є надлюдиною, нам лише потрібно «видобути» ïï з себе, «подолавши» в собі своє людське начало, «вижити» із себе слабку «останню» людину.

Відзначено, що подібне вивищення власної (надлюдської) сутності над усім низьким, незмінним i людським («занадто людським») можливе лише в колі вічного повернення, через яке людина здійснює своє призначення, реалізує мету власного життя та вершить свою долю - самоперевершується та стає надлюдиною. Саме тому ніцшеанське вічне повернення може бути трактоване як ідеальна програма людської самореалізації, вічне становлення людини, iї шлях до самої себе, іï повернення до власної сутності, до себе справжньої, до оновленого, «покращеного» варіанту себе самої.

Акцентовано, що, лише долаючи саму себе, людина підіймається до найвищого утвердження життя, адже, переживаючи постійний «жах» вічного повернення та радісно вітаючи всі перспективи, які воно перед нами відкриває, людина не тільки створює саму себе, вона ще й перестворює наново увесь світ. Для цього їй потрібна неабияка сила волі, точніше, воля до влади, яка у філософії Ніцше виступає не як жага до панування, а як влада людини над собою, як свобода її самовираження через внутрішню силу духу й самовладання. Таким чином, вдосконалюючись і самоперевершуючи себе, людина досягає більших висот власної самореалізації.

Ключові слова: Ф. Ніцше, вічне повернення, надлюдина, «остання» людина, воля до влади.

\section{Summary}

Sinelnikova $M . V$. Nietzsche's eternal recurrence as a way to oneself. - Article.

The article is devoted to the study of Nietzsche's idea of eternal recurrence and the problem of its various interpretations. It is noted that this concept is the foundation of all Nietzschean philosophy, which unites other key ideas of the thinker, such as the superman, the "last" man, the will to power, the "death" of God, amor fati. It is emphasized that man is portrayed by Nietzsche as a dual being, because it equally represents two opposite principles - human and superhuman. It is emphasized that according to Nietzsche, each of us is potentially already a superman, we just need to "get" it out of ourselves, "overcoming" our human origin, to "survive" a weak "last" person.

It is noted that such a proclamation of one's own (superhuman) essence over everything low, unchanging and human ("too human") is possible only in the circle of eternal recurrence, through which a person fulfills his purpose, realizes the purpose of his own life and decides his destiny. That is why Nietzsche's eternal recurrence can be interpreted as an ideal program of human selfrealization, the eternal formation of man, his path to himself, his return to his own essence, to himself, to the renewed, "improved" version of himself.

It is emphasized that only by overcoming oneself does one rise to the highest assertion of life, because experiencing the constant "horror" of eternal recurrence and joyfully welcoming all the prospects it opens before us, man not only creates himself, he also transforms the whole world. To do this, it needs a remarkable willpower, or rather the will to power, which in Nietzsche's philosophy acts not as a thirst for domination, but as a man's power over himself, as freedom of self-expression through the inner strength of spirit and self-control. Thus, by improving and surpassing himself, man reaches greater heights of his own self-realization.

Key words: F. Nietzsche, eternal recurrence, superman, "last" man, will to power. 